The relationship between critical thinking ability and listening comprehension ability of Iranian EFL learners

\author{
Nour Mohammadi, Esmaeel \\ University of Sistan and Baluchestan, Zahedan, Iran (Esmaeel.nm@gmail.com) \\ Zare, Zahra $\bowtie$ \\ University of Sistan and Baluchestan, Zahedan, Iran (Zahrazare17790@yahoo.com)
}

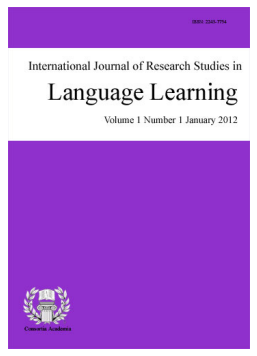

ISSN: 2243-7754 Online ISSN: 2243-7762

OPEN ACCESS

\title{
Abstract
}

The present study was conducted to identify the relationship between critical thinking ability and listening comprehension ability of Iranian EFL learners. It also, investigated difference between the learners with high and low critical thinking ability and their listening comprehension ability. The participants of this study were 100 males and females, who majoring in English Translation and English Literature at Azad University of Shiraz and Sistan and Baluchestan University. A critical thinking questionnaire and a TOFEL listening comprehension test were used as instruments of this study. The results of this study revealed that there was a strong positive significant correlation between critical thinking ability and listening comprehension ability. In order to investigate difference between learners with high and low critical thinking ability and their listening comprehension an independent sample t-test was employed, and the results showed a significant difference between the learners with high and low critical thinking ability and their listening comprehension ability.

Keywords: critical thinking; listening comprehension; EFL learners 


\section{The relationship between critical thinking ability and listening comprehension ability of Iranian EFL learners}

\section{Introduction}

The literature on language skills is very dense, and as a result, an extreme amount of resources dealing with the significance of speaking, writing and reading exists, though, recently, there has been an important focus on listening skill in education and training. Brown (2001) acknowledged that listening is a significant skill through which language learners internalize linguistic information without which they cannot produce language. Listening is an important language skill to develop in terms of second language acquisition (SLA) (Dunkel, 1991; Rost, 2001; Vandergrift, 2007). However, in spite of the fact that listening has subjected to research for more than three decades, compromises on a definition of listening has never been reached among language researchers. Morley (1972) defines listening comprehension as the ability not only to discriminate auditory grammar, but also to reauditorize, extract essential information, remember it, and relate it, everything that entails processing sound and construction of meaning. Neisser (1976) views listening comprehension as a temporally constant process in which the listener anticipates what will come next. Goss (1982) defines listening comprehension as a mental process in which the listeners attempt to construct a meaning out of the information received from the speakers.

Listening has been at the heart of language learning. Long ago, listening comprehension used to be measured as a passive activity and did not worth researchers' attention (Jung, 2003; Thompson \& Rubin, 1996; Vandergrift, 2004). Listening comprehension is an inferential process (Rost, 2002). Listening comprehension is considered hypothetically like a dynamic development that those pay attention to selected features, and associate their hearing with accessible information and comprehension. Critical Thinking is the process of using logic to discriminate what is true, and what is false. Astleitner (2007) claimed that critical thinking is superior thinking skills that contains assessing attitude, and is a strong-minded decision which trimmings in understanding, examination, estimation, and deduction. Critical thinking was the employ of rationale in a comprehensive and competent manner in individual judgment, performance, and idea (Noddlings, 2006). Findings have proved that critical thinking is considerably and optimistically correlated with academic achievement (Jenkins, 1998; Facione, Blohm, Howard, \& Giancarlo, 1998; Collins \& Onwuegbuzie, 2000). In sum, Dewey (1933) states that the central purpose of education is learning to think.

\subsection{Statement of the Problem and the Purpose of the Study}

Among the different factors that may influence listening comprehension ability, critical thinking is of utmost importance. The relationship between critical thinking ability and listening comprehension ability will be explored in this study. Therefore, the specific problem under investigation in present study is to discover the relationship between critical thinking ability and listening comprehension ability. Iranian EFL learners are not effectively familiar with the idea of critical thinking. Usually, they admit many ideas without making any endeavor to judge them in terms of truthful pieces of evidence. There is a general agreement among scholars that critical thinking can be significant in almost every activity due to its association with the abilities such as problem solving and decision making.

In educational setting, it is extensively acknowledged that learning to think is one of the most significant goals of official schooling. Dewey (1933) declared that the central purpose of education is learning to think. As part of the education, learners need to extend and learn to apply critical thinking skills to their academic studies effectively (Kealey, Holland, \& Watson, 2005), to the complex problems that they will face in their professions (Yeh, 2004), and to the critical choices they will be forced to make as a result of the information explosion and other rapid technological changes (Oliver \& Utermohlen, 1995). Also, more recently, ways in which critical thinking might be deduced and taught have become extremely debated questions for L2 learning scholars and 
The relationship between critical thinking ability and listening comprehension ability of Iranian EFL learners practitioners (Thompson, 2002). However, the skill of listening had been neglected in the L2 literature until recently. L2 researchers considered Listening as ability that could be developed without assistance, and a deep investigation into the history of language learning reveals this lack of attention to the skill of listening (Chiang \& Dunkel, 1992; Morley, 1984; Moyer, 2006; Mendelsohn, 1998; Schmidt-Rinehart, 1994).

The neglect of the listening skill was accompanied with an ongoing debate about which of the four language skills (speaking, listening, reading, and writing) is the most crucial for the learning and acquisition of a second language. However, past research has thus far revealed that a large proportion of the L2 research findings indicates that listening is the most important skill for language learning because it is the most widely used language skill in normal daily life (Rost 2002), and it develops faster than the three other language skills, which in turn suggests that it can facilitate the emergence of the other language skills (Oxford, 1990). The present study tries to consider the relationship between critical thinking and listening comprehension of EFL learners. It also investigates if there is any significant difference between learners with high and low critical thinking and their listening comprehension ability.

\subsection{Significant of the Study}

Listening plays an important role in communication as it is said that, of the total time spent on communicating, listening takes up 40-50\%; speaking, 25-30\%; reading, 11-16\%; and writing, about $9 \%$ (Gilakjani \& Ahmadi, 2011; Mendelsohn, 1994). Listening is the mainly commonly employed speech ability (Morley, 1999; Scarcella \& Oxford, 1992). Bird (1953) discovered that university students devoted 42 percent of their entirety oral announcement time to listening whereas they devoted 25 percent to speaking, 15 percent to reading, and 18 percent to writing.

Barker, Edwards, Gaines, Gladney, and Holley (1980), carried out a study on Bird's view of the primacy of listening and the results of this study revealed that university learners devoted 52.5 percent of their time to listening, 17.3 percent to reading, 16.3 percent to speaking, and 13.9 percent to writing. Devine (1982) claimed that listening is the most important devices that received thoughts and knowledge are gotten from Gilbert (1988), and also discriminated that learners from kindergarten throughout high school were anticipated to listen 65-90 percent of their point in time. While, Wolvin and Coakley (1988) stated that in and out of the classroom, listening employs supplementary of every day announcement time than other forms of verbal communication. Listening is fundamental to the livings of students through every stages of learning improvement (Coakley \& Wolvin, 1997; Feyten, 1991; Wing, 1986).

Ferris (1998) and Murphy (1991) considered that listening is the most commonly employed language ability in the classroom. Both scholars (Ferris \& Tagg, 1996) and learners (Ferris, 1998) recognize the significance of listening understanding for achievement in educational situations. Many studies signified that competent listening abilities were more significant than reading skills as a feature causative to educational achievement (Coakley \& Wolvin, 1997; Truesdale, 1990). Critical thinking has been one of the most centers of attention, subject while the ancient times. As Mason (2007) exactly declares, numerous theorists have improved assumption of critical thinking. In addition, Mok (2010) utters that critical thinking includes two significant features. One feature is in relation to the education and the second feature is in relation to classroom training. By regarding to education, it is important to manage learning in a manner that helps learners in their learning. As result, the critical thinking procedure should be accessible for learners to distinguish the critical aspects of dissimilar critical outlooks. Regarding to classroom training, the competent apply of teacher questions, and contribution of learners in reliable negotiations can utilize learners in significant critical thinking procedures.

This study will attempt to demonstrate if there is any statistically significant relationship between critical thinking and listening comprehension, it will also attempt to investigate the difference between learners with high and low critical thinking ability and their listening comprehension ability .Thus current study can assist educational decision makers in recognizing the extent to which learners thinks critically, and it can assist 
teachers become conscious of the importance of increasing learners critical thinking skill and training them how to employ this skill to be successful in diverse procedures of education. As mentioned before, present study attempted to consider the relationship between critical thinking and listening comprehension. It also investigated the difference between learners with high and low critical thinking ability and their listening comprehension. By considering these purposes, the researchers tried to answer these questions:

Q1: Is there any statistically significant relationship between critical thinking ability and listening comprehension of Iranian EFL learners?

Q2: Is there any statistically significant difference between learners with high and low critical thinking ability and their listening comprehension ability?

\section{Literature Review}

\subsection{Listening Comprehension}

New cognitive research has given us a better understanding of the listening comprehension process. Understanding spoken language is basically an inferential process (Rost, 2001). Many researchers in SLA have paid attention to both top-down processing and bottom-up processing in listening comprehension. Listening process models are in three types: bottom- up process, top- down process and interactive process.

Hamouda (2013) investigated the listening problems encountered by a group of first year English major students of Qassim University. The participants of this study were 60 students who received the listening course. Data was collected using questionnaires and interviews. The outcomes of the study demonstrated that accent, pronunciation, speed of speech, inadequate vocabulary, different accent of speakers, lack of attentiveness, nervousness, and bad quality of recording were the major listening comprehension problems encountered by EFL Saudi learners. Understanding students' learning troubles may make it possible for EFL teachers to help students increase efficient learning strategies and finally improve their English listening abilities. Proposals are prepared for addressing problems about how teachers can help their students overcome listening comprehension problems. The results of this study may also be practical for those who are paying attention to this field.

To determine the relationship between self-esteem and listening comprehension of EFL students, Hayati (2008) carried out a study at the Shahid Tondgouyan Petroleum University of Abadan, Iran. Sixty intermediate students (30 male and 30 female) were chosen using a sample proficiency test and Students' English language listening comprehension scores were considered using a model test of TOEFL, including 34 audio conversations and 34 written form tests, and their self-esteem was estimated using Coopersmith's (1967) questionnaire. The results demonstrated that the students' listening comprehension was significantly affected by their self-esteem; that is, self-esteem as a psychological factor had a positive relationship with students' English language listening comprehension.

Modirkhamene and Rezazade (2012) examined the probable relationship between Gardner's eight intelligence types and listening comprehension. The participants of this study were 75 (39 females and 36 males) intermediate EFL learners. Intrinsic in this examination was the supposition that not all the eight gates of intelligence expect success in the target language listening tasks to the similar power because this relationship may differ depending on the context where it is examined. In order to assess the participants' multiple intelligences and listening ability, a highly dependable MI-based questionnaire developed by Armstrong and a TOEFL Listening test were applied. Using the enter method; an important model emerged from the data offered to a sequence of multiple deterioration analyses. In addition, of the eight intelligences, visual and interpersonal intelligences demonstrated a powerfully positive relationship with the listening test scores of both males and females. It was concluded that intelligences-based EFL instruction granted chances to determine, value and improve the abilities of EFL learners in better undertaking language learning. 
Bagherzadeh Kasmani and Davoudy (2013) considered the impact of using audio CD on reading comprehension of pre- intermediate Iranian EFL learners as one of the most essential issues in language studies. The question this study tries to answer is whether there is a relationship between listening and simultaneous reading. To answer this question, 200 students of translation training program from the Islamic Azad University of Rasht were elected and were tested on OPT test. After OPT, 60 homogeneous students were accidentally allocated to two groups, 30 in control and 30 students in experimental group. They were taught and tested on different forms of reading. The data of the study was evaluated through t- test and ANCOVA. The relationship between the variables of the study was confirmed, rejecting the null hypothesis of the study. With extra documentation into the aspect of aural stimuli and reading, educators will be able to expand and broaden knowledge for the present and future generations.

Amiri, Jahandar, and Khodabandehlou (2012) conducted to investigate the relationship and the impact of awareness of form class on Iranian EFL learner's listening comprehension at KISH central branch institute, Tehran, Iran. This study concentrated on intermediate learners. The participants of this study were 232 adult EFL learners. Therefore, 70 learners were chosen randomly as the participant of this study and they were separated into experimental and control groups, each group with 35 learners. Subsequently, having being homogenized by an OPT (Oxford Placement Test) after that both groups sat for a pre-test which was TOEFL listening comprehension test. The purpose of this test was to compute the learner's initial knowledge of listening comprehension ability. After listening comprehension pre-test the learners arranged for the awareness structural linguistic test, in order to approximate their awareness knowledge level. After pretest listening both control and experimental groups sat for awareness test in order to estimate their linguistic structure levels. Afterwards, the experimental group received treatment based on linguistic structure test awareness (verbs, nouns, adjectives, and adverbs).But, the control group received no treatment. The treatment was within 8 weeks, and each session 30 minutes were specified for teaching syntactic structures. Finally, at the end of the course both groups sat for the post -test of listening comprehension. Then the statistical analysis was through ANCOVA. It was investigated from the study that learner's awareness (verbs, nouns, adjectives, and adverbs) of form class enhanced listening ability. So, the experimental group did better than the control group according to the post-test observation.

Barta (2010) considered the verbal report methodology to study what listening comprehension sub-skills and strategies can be known in test takers' thought processes through the task-solving procedure. The significance of the research lies in providing a new aspect to and as a result of complementing the existing listening comprehension classifications, which are based on either theoretical assumption or quantitative research methods. The input for the retrospectees consisted of the listening stimuli (two texts) and two tasks: multiple choice questions and table completion. Fourteen Hungarian retrospectees of level B1-B2 performed both tasks and presented verbal protocols on their thought processes. One part of the protocol data was used to alter and confirm a literature-based beginning coding scheme by measuring the data against the scheme, which capitulated a classification of listening sub-skills and strategies. It was then tested on the rest of the double-coded protocol segments by starting inter-coder dependability through percent conformity and Cohen's kappa. The study of this classification showed that listening for test-taking purposes, which is a non-interactive, stressful, high-stake condition, is distinguished by direct dependence on schematic relations to possible referents, a constant communication of the aural and written input in the cognitive processes and a strong tendency to extract forced responses.

\subsection{Critical Thinking}

Although there is no compromise on critical thinking's definition. Kadir (2007) conserves the need of agreement in describing critical thinking is associated with special point of views of thinking and psychology. In fact, theorist pays attention to the concept of critical thinking, whereas psychologists pay attention to the concept of critical thinking abilities. The most generally accounted definitions are predisposed to be extensive, signifying that critical thinking is a rational, thoughtful process linking both skills and dispositions (Ennis, 1987). 
Paul, Elder, and Bartell (1997) claim that the historical roots of critical thinking are prehistoric and return to the training performance and vision of Socrates 2500 years ago. Socrates was the one who recognized a technique of examining and inquiring for their authentications to facts. Plato, Aristotle, and the Greek doubters pursued Socrates' performance. They thought that stuffs are often diverse from what they look to be, and only the knowledgeable brain is capable to observe the authenticity of stuffs. Consequently require to think methodically appeared from this prehistoric Greek custom. Throughout the Renaissance, numerous researchers in Europe began to think critically regarding diverse issues like as religious conviction, painting, human being environment, and so on, through the faith that the majority of the dominances of human being living required exploration, examination, and analysis. In the 20th century, the important require for critical thinking in living and schooling was recognized. At the present; the importance of critical thinking and its authority have turned out to be increasingly more obvious.

Myers and Dyer (2006) considered the consequence of students' learning style on critical thinking ability. In order to perform this study, 135 learners participating in the cultivation and living sciences guidance classes at the University of Florida were chosen. The Gregorc Style Delineator was managed to assess the favored learning styles of every learner. To find out the critical thinking abilities of every learner, the Cornell Critical Thinking test was employed. No distinctions were created between the critical thinking abilities of male and female learners. But, learners with very fixed theoretical chronological learning styles favorites demonstrate considerably upper critical thinking scores. No distinctions in critical thinking ability were between learners of other learning styles.

Hosseini et al. (2012) considered the correlation between critical thinking, reading comprehension and reading strategies of English university students. The participants were 70 randomly selected junior and senior EFL students, majoring in English Literature and English Translation at Arak University and Shahrekord University. The data was collected through the TOEFL (Test of English as a Foreign Language) reading comprehension test, a critical thinking ability test and Reading Strategy Inventory. The findings reveal that there was a significant positive relationship between Iranian English as a Foreign Language (EFL) readers' critical thinking ability and reading strategy use. Moreover, a significant positive correlation was observed between critical thinking and reading compensation. Results also revealed that cognitive and affective strategies along with critical thinking ability act as the best predictors of reading.

Magno (2010) studied the role of meta-cognitive skills in increasing critical thinking. In order to perform the purpose of this study, the Watson-Glaser Critical Thinking Appraisal and the meta-cognitive Assessment Inventory were given to 240 Freshmen College students who were taking their first year in college in Philippines. In order to discover the effect of meta-cognition on critical thinking, the Structural Equation Modeling (SEM) was engaged. The Pearson Product Moment correlation process discovered that the aspects of meta-cognition are significantly associated with the aspects of critical thinking.

\section{Method}

\subsection{Participants}

The participants of this study were selected from two cities because of availability limitation and also this limitation was helped to homogeneity of participants in terms of social background. Participants were 100 senior Iranian learners, who majoring in English Translation and English Literature at Shiraz Azad University and Sistan and Baluchestan University (Iran). The participants' age varied between 20 to26.

\subsection{Instruments}

Two kinds of instruments were required for this study, TOEFL Listening Comprehension Test and Critical Thinking Questionnaire. The critical thinking questionnaire was adopted from unpublished M.A. thesis of 
The relationship between critical thinking ability and listening comprehension ability of Iranian EFL learners

Dehghan Niry, which in turn was adapted from the thesis of Naeini (2005). Naeini (2005) acknowledged that the English translation of critical thinking questionnaire was interpreted by her to warranty the complete understanding of the questions by the participants, She reports that after getting the feedback from the students, and the reliability of this questionnaire 0.86.TOFEL Listening Comprehension Test which was adapted from TOFEL Test Preparation Kit Workbook (2003) (second edition).

First, Critical Thinking Questionnaire and then TOFEL Listening Comprehension Test were administered to the participants. The participants were demanded to choose the proper responses to the questions. The questionnaire and the test organization seized about 30 minutes. After, gathering the done questionnaire, and test sheets, researcher examined the information throughout utilizing the Statistical Package for Social Sciences (SPSS). While this study planned to discover the correlation between critical thinking and listening comprehension ability, Pearson Product- Moment Correlation was employed. A t-test was as well used to examine the difference between the learners with high and low critical thinking ability and their listening comprehension ability.

\subsection{Data Analysis and procedures}

The data will be submitted to Statistical Package for Social Science (SPSS) to be analyzed.

For the first hypothesis, Pearson product -moment correlation coefficient was used in order to see if the relationship between the critical thinking ability and listening comprehension of Iranian EFL learners is statistically significant or not; and then the researcher determine whether it is meaningful or not. For the second hypothesis, an independent sample of t-test was applied to see if the difference between the listening comprehension ability of learners with high and low critical thinking ability is statistically significant or not.

\section{Results and Discussion}

Question 1: Is there any statistically significant relationship between critical thinking ability and listening comprehension of Iranian EFL learners?

To respond the beyond question, Pearson Product-Moment Correlation was employed. Now, for computing Pearson $\mathrm{r}$, critical thinking has been considered as an independent variable and listening comprehension as the dependent variable. According to Table 1, by computing the relationship, researcher discovered a positive and significant relationship between critical thinking ability and listening comprehension ability. Results signified that listening comprehension were significantly associated with critical thinking, with the observed value of Pearson $r=0.779$ at the 0.05 level of significance. This strong positive and significant value of Pearson $r$ signifies that learners' critical thinking ability has a positive and significant relationship with their listening comprehension.

\section{Table 1}

Correlation between Critical Thinking and Listening Comprehension

\begin{tabular}{cc}
\hline Critical Thinking & Listening Comprehension \\
\hline $\mathrm{r}$ & $0.779^{* *}$ \\
sig. & 0.00 \\
$\mathrm{~N}$ & 100 \\
\hline Note. ${ }^{* *}$ Correlation is significant &
\end{tabular}

This strong positive and significant value of Pearson's $r$ can imply that the critical thinking ability of learners is strongly and positively related to their listening comprehension ability. 
Nour Mohammadi, E., \& Zare, Z.

Question 2: Is there any statistically significant difference between learners with high and low critical thinking ability and their listening comprehension ability?

Table 2 shows the related descriptive statistics for critical thinking ability and listening comprehension ability.

Table 2

Descriptive statistics of learners with high and low critical thinking ability $(N=100)$

\begin{tabular}{ccc}
\hline Critical Thinking & High & Low \\
\hline N & 53 & 47 \\
M & 3.9547 & 2.2936 \\
SD & 0.65825 & 0.47521 \\
Max. & 3.2 & 1.00 \\
Min. & 5.8 & 3.00 \\
\hline
\end{tabular}

According to the Table, the mean score of the participants on the critical thinking questionnaire was 3.16, with the SD of 0.3726 . The mean score of them on the TOFEL listening comprehension test was 15.87 , with the SD of 5.067. To find out if the difference between the learners with high and low critical thinking ability and their listening comprehension ability is significant, a t-test was employed. As you see Table 3 presents the results.

Table3

T-test of learners with high and low critical thinking ability differences on listening comprehension ability

\begin{tabular}{lccccc}
\hline Leven's Test for Equality & \multicolumn{1}{c}{ Variance T-test for Equality of Means } & \\
\hline & $\mathrm{F}$ & Sig. & $\mathrm{T}$ & $\mathrm{df}$ & Sig (2-tailed) \\
\hline Equal Variances Assumed & 2.034 & 0.102 & 2.042 & 97 & 0.43 \\
Equal Variance not Assumed & 2.221 & & 97.696 & & 0.29 \\
\hline
\end{tabular}

As Table 3 shows, there was a significant difference between learners with high and low critical thinking ability and listening comprehension ability, $($ sig. $=.043, \mathrm{sig} .=.029), \mathrm{t}(98)=2.221, p<0.05$. This indicates that learners with high and low critical thinking ability have different listening comprehension abilities and the difference between learners with high and low critical thinking ability and listening comprehension ability is significant.

\section{Discussion}

Critical thinking is the ability which individuals make use of to analyze facts, produce and organize ideas, defend opinions, make comparisons, draw inferences, evaluate arguments and solve problems (Chance, 1986, p.6). The findings of this study appear to verify the significant position of critical thinking ability in listening comprehension ability. As stated previous to, the findings of data analysis showed that there were an important positive correlation between critical thinking and listening comprehension ability, $\mathrm{r}(98)=0.779, p<0.05$, (see Table 1 above). This signified that critical thinking ability of Iranian students was strongly correlated with their listening comprehension ability and those who thought more critically had better listening comprehension; those who had superior critical thinking ability gained high listening comprehension ability scores. This result can emphasize the significant position of critical thinking in education and is in concurrence with previous studies as stated in review of literature.

Kamali and Fahim (2011) have concluded that it is extremely significant to contain the skill to reflect critically for learners who desire to be triumphant in schooling. Results of this study confirm the finding of Bagherkazemi and Birjandi (2010) that inspected the correlation between EFL teachers' critical thinking skill and their student-evaluated professional success. They concluded that there were statistically significant relationship between teacher's critical thinking skill and their student- evaluated professional success. Results of present 
The relationship between critical thinking ability and listening comprehension ability of Iranian EFL learners

study also support the claim of Ghaemi and Taherian (2011) that considered the correlation between EFL teachers' critical thinking and their teaching success. They demonstrated that there is a significant relationship between EFL teachers' critical thinking and their teaching success. According to them the improvement of EFL teacher's critical thinking skill is paralleled to improvement of their teaching success. Kamali and Fahim (2011) inspected the correlation between critical thinking skill, resilience, and reading comprehension of texts containing unknown vocabulary items.

Result of study discovered that (a) the ranks of critical thinking had a considerable consequence on the participants' scores on the resilience level, (b) the ranks of critical thinking had an important consequence on the participants' understanding of texts with unfamiliar vocabulary items, and (c) the ranks of resilience had a considerable consequence on the participants' understanding of texts with unfamiliar vocabulary items. To find out the correlation between self-esteem and listening comprehension of EFL students, Hayati (2008) carried out a study at Shahid Tondgouyan Petroleum University of Abadan, Iran. The results demonstrated that the students' listening comprehension was significantly affected by their self-esteem; that is, self-esteem as a psychological factor had a positive relationship with students' English language listening comprehension. Modirkhamene and Rezazade (2012) examined the probable relationship between Gardner's eight intelligence types and listening comprehension. In addition, of the eight intelligences, visual and interpersonal intelligences demonstrated a powerfully positive relationship with the listening test scores of both males and females. It was concluded that intelligences-based EFL instruction granted chances to determine, value and improve the abilities of EFL learners in better undertaking language learning. By evaluating results of these five studies and this study, it was accomplished that there is a strong positive relationship between critical thinking skill and learning skills and that it is very significant skill for students to improve and enhance their language learning and also perform successfully in their language learning, although no study was done between critical thinking ability and listening comprehension ability.

The analysis of the results signified that the learners with high critical thinking ability $(\mathrm{M}=3.9547, \mathrm{SD}=$ $0.65825)$ and learners with low critical thinking ability $(\mathrm{M}=2.2936, \mathrm{SD}=0.47521)$ were different also in their listening comprehension abilities (see Table 3). The results of an independent-samples t-test also demonstrated that the difference between the learners with high and low critical thinking ability and their listening comprehension abilities were significant. So, the researcher concluded that the learners who are more critically in their thoughts are more successful in their listening comprehension abilities and also by improving their listening comprehension abilities they can improve their language learning skills and also improve their way of learning. Also, critical thinking develops understanding by serving students examine the reasonable organization of the textbooks.

\section{Implications of the study}

This section consists of the theoretical and pedagogical implications of the study.

\subsection{Theoretical Implications}

The present study focused on the significant role of critical thinking ability in the listening comprehension of Iranian EFL learners. It signified that critical thinking generally is related to language learning and specifically to the development of listening comprehension. The result of this study revealed that those who were more critical thinkers improved better their listening comprehension ability and finally were more successful in listening comprehension.

Listening is the most frequently used language skill in the classroom (Ferris, 1998; Murphy, 1991; Vogely, 1998). Both instructors (Ferris \& Tagg, 1996) and students (Ferris, 1998) recognize the significance of listening comprehension for success in academic settings. Many studies specified that efficient listening skills were more important than reading skills as a factor contributing to academic success (Coakley \& Wolvin, 1997; Truesdale, 
1990). The findings of the present study revealed that critical thinking of Iranian EFL learners positively and significantly correlated with the listening comprehension ability. Iranian EFL learners' critical thinking should be increased because their way of thinking associated with their actions while listening comprehension ability. So, Iranian EFL learners should pay more attention to critical thinking rather than just using learning strategies. According to Fahim and Komijani (2010), when critical thinking becomes part of the ongoing education, it makes students become more successful and helps them successfully integrate with their society. Considering these benefits, it is important to provide some opportunities for the promotion of critical thinking skills.

\subsection{Pedagogical Implications}

According to $\mathrm{Ku}$ (2009), an important purpose of modern education, is to teach the elements of critical thinking. Critical thinking provides students with the competency necessary to deal quickly and effectively with ever accelerating changes of the new world. To develop such competency, students must go beyond textbook-knowledge absorption and learn to build up flexible intellectual skills concerned with information-valued judgment, evidence-based evaluation, and reason-driven argument. Critical thinking is not only essential for students to perform well in school, but also needed in future workplaces, social and interpersonal contexts where appropriate decisions are to be made carefully and independently on a daily basis.

The pedagogical implication of the present study may be practical, applicable and useful for syllabus designers, materials developers and language teachers and learners.

The findings of this study showed that critical thinking ability of Iranian EFL learners positively and strongly related to the listening comprehension ability. Paul and Elder (2005) relate learning and thinking by stating that "the only capacity we can use to learn is human thinking (p.10)". It can be concluded that the employment of critical thinking skills would help EFL learners learn listening comprehension more efficiently and profoundly. This study encourages syllabus designers, materials developers and language teachers to consider critical thinking as one of the effective elements for academic and career success. In order to have educated students who are able to efficiently apply critical thinking skills, syllabus designers and material developers are recommended to make course books that consider critical thinking as one of the efficient elements for academic and career success. Designing courses which particularly focus on prompting studentse critical thinking and increasing their strategic intent will result in educating educated students with analytical abilities that aid them to carry out successfully. Also, the present courses can be reorganized to challenge students to apply critical thinking skills to achieve academic success.

As language teachers seek to make the language classroom an effectual milieu for learning, it has become noticeable that "teaching learners how to learn" is important. Since it has been understood that critical thinking is significantly related to the listening comprehension, this study has some implications for teachers. In this way, they are suggested to teach critical thinking skills openly. Halpern (1999) points out that "there are identifiable critical thinking skills that can be taught and learned, and when students learn these skills and apply them appropriately, they become better thinkers" (p. 70). He also considers that college students should get precise instruction in how to think. So, teachers of listening courses should focus on critical listening while giving priority to this aim in their teaching: teaching learners critical thinking skills to develop their ability to think critically. Teachers should know that the encouragement of the learnerse critical thinking will develop the success of their listening comprehension. Finally, the researcher considers the results got from the present study may be practical for those concerned with language teaching to assist language learners develop their way of thinking, think more critically, and listen more purposefully.

\section{Conclusion}

This study was performed to find out if there is any statistically significant relationship between critical thinking ability and listening comprehension ability of Iranian EFL learners. The differences between the 
The relationship between critical thinking ability and listening comprehension ability of Iranian EFL learners

learners with high and low critical thinking ability and their listening comprehension were also investigated. The results of the study signified that there was a strong positive and significant correlation between critical thinking ability and listening comprehension ability. It implies that learners who thought more critically develop better listening comprehension ability. Furthermore, the results revealed that differences between learners with high and low critical thinking ability and their listening comprehension were significant. It indicated that learners with higher level of critical thinking ability had better listening comprehension ability. The gained strong positive relationship between critical thinking and listening comprehension ability can sustain the results of numerous preceding studies that examined relationship between critical thinking and language learning's achievement in development of learner's learning. According to review of literature, numerous additional studies there are that confirm the relationship between critical thinking and diverse features of language learning (e.g. Myers\& Dyer, 2006; Fahim et al., 2010; Kamali \& Fahim, 2011; Mango, 2010).

As a conclusion, since of the important function of critical thinking ability in enhancing learning, it is necessary to promote critical thinking ability among language learning. Therefore, increasing learners critical thinking is one of tasks of language teachers, course developers and educations planners. Present study suggests teachers develop critical thinking of learners and learners' consciousness of listening ability concurrently since their incorporation should lead to an improved listening comprehension.

Acknowledgements: I wish to express my gratitude firstly to the grate and compassionate God, and then to my professor Dr. Esmaeel Nour Mohammadi, who helped me during my thesis and I am also thanks to the Iranian EFL learners for their assistance in collecting the data for this study, Most of all, Thanks also my family especially my sister who encouraged me during this research.

\section{References}

Astleitner, H. (2007). Teaching critical thinking online. Journal of Instructional Psychology, 29(2), 53-77. Barjesteh, H., \& Vaseghi, R. (2012). Critical thinking: A reading strategy in developing English reading comprehension performance. Journal of Sheikhbahaee English Foreign Language, 1(2), 21-34.

Barker, L., Edwards, R., Gaines, C., Gladney, K., \& Holley, F. (1980). An investigation of proportional time spent in various communication activities by college students. Journal of Applied Communication Research, 8, 101-110. http://dx.doi.org/10.1080/00909888009360275

Bird, D. (1953). Teaching listening comprehension. Journal of Communication, 3, 127- 130.

Brown, H. D. (2001). Teaching by principles: An interactive approach to language pedagogy ( $2^{\text {nd }}$ ed.). White Plains, NY: Pearson Education.

Chiang, C., \& Dunkel, P. (1992). The effect of speech modification, prior knowledge, and listening proficiency on EFL lectures learning. Journal of TESOL Quarterly, 26(2), 345-374. http://dx.doi.org/10.2307/3587009

Coakley, C., \& Wolvin, A. (1997). Listening in the instructive situation, listening in everyday life: A personal and professional approach (pp. 179-212). Lanham, MD: University Press of America.

Collins, K. M., \& Onwuegbuzie, A. J. (2000). Relationship between critical thinking and performance in research methodology courses. Article accessible at the Annual Conference of the Mid-South Educational Research Association, Bowling Green, KY.

Cottrell, S. (2005). Critical thinking abilities, developing effective analysis and argument. New York: Palgrave Macmillan.

Devine, T. G. (1982). Teaching study abilities. Boston, MA: Allyn, \& Bacon.

Dewey, J. (1993). How to think: Restatement of the relation of reflective thinking to the educational process. Lexington, MA: D. C. Heath.

Dunkel, P. (1991). Listening in the native and second/ foreign language: Toward an integration of research and practice. Journal of TESOL Quarterly, 25, 431-457. http://dx.doi.org/10.2307/3586979 
Nour Mohammadi, E., \& Zare, Z.

Ennis, R. (1996). Critical thinking appraisal. Journal of Theory into Practice, 32(3), 179-186. http://dx.doi.org/10.1080/00405849309543594

Facione, P., Facione, N. C., Blohm, S. W., Howard, K., \& Giancarlo, C. A. F. (1998). California critical thinking skills test. Millbrae, CA: California Academic Press.

Fahim, M., \& Komijani, A. (2010). Critical thinking ability, L2 vocabulary knowledge, and learning strategies. Journal of English Studies, 1(1), 23-38.

Ferris, D. (1998). Students' views of academic audio/spoken abilities: A relative needs analysis. Journal of TESOL Quarterly, 32, 289-318. http://dx.doi.org/10.2307/3587585

Ferris, D., \& Tagg, T. (1996). Educational listening/speaking tasks for ESL students: Problems, suggestions, and implications. Journal of TESOL Quarterly, 30, 297-320. http://dx.doi.org/10.2307/3588145

Feyten, C. M. (1991). The power of listening ability: An overlooked dimension in language acquisition. Journal of Modern Language, 75(2), 173-180. http://dx.doi.org/10.1111/j.1540-4781.1991.tb05348.x

Gilakjani, A.P., \& Ahmadi, M.R. (2011). A study of factors affecting EFL learners' English listening comprehension and the strategies for improvement. Journal of Language Teaching and Research, 2(5), 977-988. http://dx.doi.org/10.4304/jltr.2.5.977-988

Gilbert, M. B. (1988). Listening in school: I know you can hear me--but are you listening? The International Journal of Listening Association, 2, 121-132. http://dx.doi.org/10.1080/10904018.1988.10499102

Goss, B. (1982). Listening as information processing. Journal of Communication Quarterly, 30, 304-307. http://dx.doi.org/10.1080/01463378209369465

Halpern, D. F. (1999). Teaching for critical thinking: Helping college students develop skills and dispositions of a critical thinker. Journal of New Directions for Teaching and Learning, 80, 69-74. http://dx.doi.org/10.1002/tl.8005

Hamouda, A. (2013). An investigation of listening comprehension problems encountered by Saudi students in the EL listening classroom. International Journal of Academic Research in Progressive Education and Development, 2(2), 113-155.

Hosseini, E., Khodaei, F. B., Sarfallah, S., \& Dolatabadi, H. R. (2012). Exploring the relationship between critical thinking, reading comprehension and reading strategies of English university students. Journal of World Applied Sciences, 17(10), 1356-1364.

Jenkins, E. K. (1998). The significant role of critical thinking in predicting auditing students' performance. Journal of Education for Business, 73(5), 274 -279. http://dx.doi.org/10.1080/08832329809601644

Jung, E. H. (2003). The role of discourse signaling cues in language listening comprehension. Journal of Modern Language, 87, 562-577. http://dx.doi.org/10.1111/1540-4781.00208

Kadir, M. A. (2007). Critical thinking: A family similarity in commencements. Journal of Education and Human Development, 1(2), 1-11.

Kasmani, M. B., \& Davoudy, S. M. (2013). The impact of using audio CD on reading comprehension of pre-intermediate Iranian learners. Journal of Social Sciences \& Humanities, 2(1), 39-50.

Kealey, B. T., Holland, J., \& Watson, M. (2005). Preliminary evidence on the association between critical thinking and performance in principles of accounting. Journal of Issues in Accounting Education, 20(1), 33-49. http://dx.doi.org/10.2308/iace.2005.20.1.33

$\mathrm{Ku}$, Y. L. (2009). Assessing students' critical thinking performance: Urging for measurements using multi-response format. Journal of Thinking Skills and Creativity, 4, 70-76. http://dx.doi.org/10.1016/j.tsc.2009.02.001

Kurita, T. (2012). Issues in second language listening comprehension and the pedagogical implications. Journal of Accents Asia, 5(1), 30-44.

Mason, M. (2007). Critical thinking and education. Journal of Educational Attitude and Hypothesis, 39(4), 337-473.

Mendelsohn, D. (1994). Learning to listen. Dominie Press: San Diego.

Mendelsohn, D. J. (1998). Teaching listening. Journal of Annual Review of Applied Linguistics, 18, 81-101. http://dx.doi.org/10.1017/S0267190500003494

Modirkhamene, S., \& Rezazade, E. (2012). The predicting power of Gardner's eight gates of intelligences 
The relationship between critical thinking ability and listening comprehension ability of Iranian EFL learners

explored in listening comprehension. Journal of World Applied Sciences, 18(4), 486-492.

Mok, J. (2010). The latest function of English language teachers: Developing students' critical thinking in Hong Kong. Journal of Asian EFL Quarterly, 12(2), 262-287.

Morley, J. (1972). Improving aural comprehension. Ann Arbor, MI: University of Michigan Press.

Morley, J. (1999). Present point of views on improving aural comprehension. Retrieved from http://www.eslmag.com/MorleyAuralStory.html

Murphy, J. M. (1991). Oral communication in TESOL: Incorporating speaking, listening, and pronunciation. Journal of TESOL Quarterly, 25, 51-75. http://dx.doi.org/10.2307/3587028

Myers, B. E., \& Dyer, J. E. (2006). The consequences of student learning style on critical thinking skill. Journal of Agricultural Education, 47(1), 43-52. http://dx.doi.org/10.5032/jae.2006.01043

Neisser, U. (1976). Cognition and reality: Principles and implications of cognitive psychology. San Francisco: W. H. Freeman.

Noddlings, N. (2006). Critical training. What our schools might teach but do not. New York: Cambridge.

O‘Malley, J. M., Chamot, A. U., Stewner-Manzanares, G., Kupper, L., \& Russo, R. P. (1985). Learning strategies employed by starting and intermediate ESL learners. Journal of Language Learning, 35(1), 21-46. http://dx.doi.org/10.1111/j.1467-1770.1985.tb01013.x

Oliver, H., \& Ytermohlen, R. (1995). An innovative teaching strategy: Using critical thinking to give learners a guide to the future. Retrieved from http://files.eric.ed.gov/fulltext/ED389702.pdf

Paul, R., \& Elder, L. (2005). A guide for educators to critical thinking competency standards. New York: Foundation for Critical Thinking Press.

Paul, R., Elder, L., \& Bartell, T. (1997). California teacher training for teaching in critical thinking: Research findings and policy recommendations. Sacramento, CA: California Commission on Teacher Credentialing.

Rost, M. (2001). Education and exploration listening. London: Longman.

Rost, M. (2002). Education and exploration listening. London, UK: Longman.

Scarcella, R. C., \& Oxford, R. L. (1992). The tapestry of language learning: The individual in the communicative classroom. Boston, MA: Heinle \& Heinle.

Schmidt-Rinehart, B. C. (1994). The effects of topic familiarity on second language listening comprehension. Journal of Modern Language, 78(2), 179-189. http://dx.doi.org/10.1111/j.1540-4781.1994.tb02030.x

Tabatabaei,O., \& Parsafar, S. M. (2012).The effect of self-directed education on critical thinking of Iranian students. Journal of Educational and Social Research, 2(2), 55-64.

Thompson, C. (2002). Teaching critical thinking in EAP courses in Australia. Journal of TESOL, 11(4), 15-20.

Thompson, I., \& Rubin, J. (1996). Can strategy training develop listening comprehension? Journal of Foreign Language Annals, 29, 331-342. http://dx.doi.org/10.1111/j.1944-9720.1996.tb01246.x

Truesdale, S. P. (1990). Whole-body listening: Developing dynamic auditory skills. Journal of Language, and Hearing Services in Schools, 21, 183-184. http://dx.doi.org/10.1044/0161-1461.2103.183

Vandergrift, L. (1997). The comprehension strategies of second language (French) listeners: A descriptive study. Journal of Foreign Language Annals, 30(3), 387-409. http://dx.doi.org/10.1111/j.1944-9720.1997.tb02362.x

Vandergrift, L. (2007). Recent developments in second and foreign language listening comprehension research. Journal of Language Teaching, 40, 191-210. http://dx.doi.org/10.1017/S0261444807004338

Vaseghi, R., Gholami, R., \& Barjesteh, H. (2012).Critical thinking: An influential factor in developing English reading comprehension performance. Journal of Asian Social Science, 1(2), 401-410.

Wing, B. H. (1986). Listening, writing, reading: Examination and application. VT: Northeast conference on Teaching of Foreign Language.

Wolvin, A. D., \& Coakly, C. G. (1988). Listening. Dubuque, IA: Wm. C. Brown. 
Nour Mohammadi, E., \& Zare, Z. 